\title{
EVALUASI HEURISTIK SISTEM PENGELOLAAN PEMBELAJARAN DARING PERGURUAN TINGGI DI INDONESIA
}

\author{
Andreas Rio Adriyanto ${ }^{1}$, Imam Santosa ${ }^{2}$, Achmad Syarief ${ }^{3}$ \\ 1,2,3,Fakultas Seni Rupa dan Desain, Institut Teknologi Bandung \\ andreasrio@students.itb.ac.id ${ }^{1}$, imamz@fsrd.itb.ac.id ${ }^{2}$, asyarief@fsrd.itb.ac.id ${ }^{3}$
}

\begin{abstract}
Abstrak
Pandemi virus Covid-19 pada awal tahun 2020 menyebabkan perubahan sistem pendidikan tatap muka ke sistem pendidikan daring. Berbagai jenis platform pembelajaran daring digunakan, salah satunya melalui sistem pengelolaan pembelajaran, Learning Management System (LMS). Perguruan tinggi di Indonesia telah mengembangkan materi ajar dalam LMS institusi masing-masing namun masih banyak kekurangan yang terdapat di LMS pembelajaran daring tersebut. Tujuan penelitian ini adalah menganalisis kebergunaan (usability) sistem tersebut termasuk materi ajar. Penelitian menggunakan strategi kualitatif dengan metode pengumpulan data dilakukan dengan pengamatan visual LMS. Data dianalisis menggunakan evaluasi heuristik dengan studi kasus pada beberapa penyelenggara pembelajaran daring. Interpretasi data diperkuat dengan studi literatur dari penelitian terdahulu. Dalam penelitian ini ditemukan permasalahan mayor pada materi ajar yang masih memakai elemen-elemen yang kurang tepat dan dapat menambah beban kognitif mahasiswa. Hasil penelitian ini memberikan beberapa rekomendasi yang dapat dijadikan salah satu pertimbangan dalam perancangan materi pembelajaran daring untuk perguruan tinggi di Indonesia.
\end{abstract}

Kata Kunci: evaluasi heuristik, LMS, pembelajaran daring

\begin{abstract}
The Covid-19 virus pandemic that occurred in early 2020 caused the education system to shift from a face-to-face education system to an online education system. Various types of online learning platforms are used, one of which is through the Learning Management System (LMS). Higher education institutions in Indonesia have developed learning materials in their LMS institutions. However, there are still many inadequacies found in their LMS. The aim of this study is to analyze the usability of the system, including the learning materials. The strategy of inquiry uses qualitative strategies, data collection method is made by visual observation of LMS. Data analysis using heuristic evaluation with case studies on several online learning providers. Data interpretation is strengthened by the study of literature from previous researches. This study found major problems in learning materials that still use elements that are not suitable and can add cognitive loads of students in constructing knowledge. The results of this study provide some recommendations that are expected to be one of the considerations in designing online learning materials for universities in Indonesia.
\end{abstract}

Keywords: heuristic evaluation, LMS, online learning 


\section{PENDAHULUAN}

Pembelajaran daring adalah pembelajaran yang materi ajarnya dikirimkan secara digital dalam jaringan (daring) internet kepada siswa di lokasi yang berbeda. Internet menjadi media utama dalam menyampaikan pengetahuan karena faktor biaya yang murah dan distribusi langsung. Pada metode tatap muka di kelas, pengajar menjadi pusat yang mengendalikan konten dan proses pembelajaran. Respon terjadi langsung dan pengajar dapat langsung memotivasi siswa. Tatap muka terbatas ruang dan waktu dan biaya pembelajaran yang semakin mahal. Dalam pembelajaran daring siswa menjadi pusat pembelajaran dan menuntut kemandirian. Fleksibilitas lokasi dan waktu dan akses yang tidak terbatas akan pengetahuan menjadi kelebihannya. Untuk pembelajaran daring asinkron dapat menyebabkan hambatan komunikasi karena respon yang tidak langsung. Butuh persiapan dan perencanaan yang baik untuk menghasilkan pembelajaran daring yang optimal. (Zhang, Zhao, Zhou, \& Nunamaker, 2004).

Kondisi ini menjadi menjadi krusial ketika dunia dilanda penyebaran virus Covid-19 pada tahun 2020. Kota dan negara di dunia menerapkan aturan agar warganya untuk tetap tinggal di rumah. Termasuk kegiatan belajar mengajar yang sebelumnya dilakukan tatap muka di kelas digantikan dengan menggunakan media internet dalam penyampaiannya. Hanya dalam sebulan dunia pendidikan bergeser dari sistem pendidikan tatap muka ke sistem pendidikan daring. Fenomena ini dimulai dari China pada pertengahan Februari 2020 dan telah diikuti oleh 74 negara dalam skala yang berbeda-beda termasuk Indonesia (Kompas, 2020)

Dalam survei yang dilakukan penulis pada 150 dosen dan 195 mahasiswa pada bulan April 2020, terlihat ketidaksiapan program studi perguruan tinggi dalam memberikan perkuliahan daring pada masa pandemi ini. Terdapat tiga platform utama yang digunakan dalam proses pembelajaran tersebut yaitu Google Classroom, instant messaging Whatsapp Group, LINE dan video conference Zoom untuk perkuliahan secara langsung (sinkron). Kendala yang dihadapi ketika perkuliahan secara sinkron adalah masalah jaringan internet dan kuota yang terbatas baik mahasiswa maupun dosen. Akibatnya materi tidak tersampaikan dengan baik. Sebaliknya dengan penggunaan instant messaging membuat frustasi mahasiswa karena ketidakjelasan materi yang disampaikan dosen pengampu dan banyaknya dosen menggantikan perkuliahan dengan tugas daripada memberikan materi ajar kepada mahasiswa. Penggunaan Google Classroom mengintegrasikan aktivitas kuliah dalam sistem, namun tergantung kesiapan dosen dalam menyiapkan materi ajar. Materi ajar berupa slide presentasi yang biasa diberikan lewat kelas tatap muka tidak dapat dipahami secara jelas oleh mahasiswa sedangkan dosen belum menyiapkan video ajar yang baik untuk penjelasan yang lebih lengkap.

Perguruan tinggi Indonesia umumnya sudah mengembangkan materi pembelajaran daring di institusinya. Materi-materi ajar disiapkan oleh dosen untuk kemudian diunggah ke dalam suatu sistem pengelolaan pembelajaran atau Learning Management System (LMS). Namun belum semua program studi menyiapkan materi ajarnya. Ketidaksiapan dalam menyiapkan pembelajaran daring lewat LMS institusi terlihat pada masa pandemi ini. Dari hasil survei yang dilakukan penulis ditemukan bahwa hanya $13 \%$ 
mahasiswa yang menggunakan LMS internal universitas dan umumnya dosen menggunakan fasilitas pembelajaran di luar institusi seperti Google, Microsoft, Zoom dan Whatsapp Group. Untuk memahami ketidaksiapan dan permasalahan yang terjadi, penelitian dijalankan dengan mengamati dan menganalisis sistem pengelolaan pembelajaran daring perguruan tinggi di Indonesia.

\section{METODE PENELITIAN}

Strategi penelitian menggunakan strategi kualitatitif. Metode penelitian dilakukan dengan cara pengumpulan data, analisis dan interpretasi data. Pengumpulan data dilakukan dengan pengamatan visual LMS penyelenggara. Analisis data menggunakan evaluasi heuristik dengan studi kasus pada penyelenggara pembelajaran daring. Interpretasi data diperkuat dengan studi literatur dari penelitian-penelitian terdahulu. Ruang lingkup difokuskan pada dimensi sistem yang terkait dengan sistem pengelolaan pembelajaran dan dimensi lingkungan yang terkait dengan materi ajar (Bhuasiri, Xaymoungkhoun, Zo, Rho, \& Ciganek, 2012). Mahasiswa pertama kali berhadapan dengan sistem pengelolaan pembelajaran daring. Sistem yang mempunyai usability yang baik dapat memberikan kenyamanan bagi pengguna terkait pemahaman dan kemudahan berinteraksi dengan sistem.

Dalam menganalisis usability suatu sistem, metode yang digunakan adalah evaluasi heuristik (Nielsen, 1994). Evaluasi ini berisi 10 variabel yang terdiri dari 1) kejelasan status sistem, 2) perbandingan antara sistem dan dunia nyata, 3) kontrol pengguna, 4) konsistensi dan standar, 5) antisipasi kesalahan, 6) mengenali daripada mengingat, 7) fleksibilitas dan efisiensi penggunaan, 8) estetika dan desain minimalis, 9) membantu pengguna mendeteksi dan menyelesaikan kesalahan, dan 10) dokumentasi dan bantuan. Masing-masing variabel diberikan skala tingkat keparahan atau Severity Rating (SR) dan rekomendasi atas permasalahan itu. Skala digunakan dari 0 sampai 4 . Nilai 0 berarti tidak ada permasalahan dan nilai 4 terdapat permasalahan utama.

Studi kasus dilakukan pada LMS yang terdapat perguruan tinggi di Indonesia yaitu ITB (Institut Teknologi Bandung) pada laman kuliah.itb.ac.id, ITS (Institut Teknologi Sepuluh Nopember) pada laman share.its.ac.id, Tel-U (Universitas Telkom) pada laman elearning.telkomuniversity.ac.id yang menggunakan LMS dengan target mahasiswa pada institusi tersebut. Pengamatan visual lainnya dilakukan pada open courseware yang diadakan oleh UGM (Universitas Gadjah Mada) pada laman elok.ugm.ac.id, UNS (Universitas Negeri Sebelas Maret) pada laman ocw.uns.ac.id dan UI (Universitas Indonesia) pada laman ocw.ui.ac.id. Open courseware merupakan pembelajaran daring terbuka yang ditujukan bagi masyarakat umum dan tidak terbatas pada mahasiswa institusi yang bersangkutan.

Pemilihan kasus tersebut didasarkan pada pengembangan Kementerian Riset Teknologi dan Pendidikan Tinggi tahun 2014 yang membuat program Pembelajaran Daring Indonesia Terbuka dan Terpadu (SPADA Indonesia). Di awal pengembangan, program ini melibatkan enam perguruan tinggi yaitu UI, ITB, UGM, ITS, Universitas Binus dan Amikom. Keberhasilan rintisan tahun 2014 dilanjutkan hingga tahun 2017 dengan 51 
perguruan tinggi penyelenggara (Kemenristekdikti, 2018). Pemilihan kasus juga mempertimbangkan klasterisasi perguruan tinggi Indonesia terbaik yang menempatkan perguruan tinggi yang dipilih termasuk 15 perguruan tinggi terbaik (Kemenristekdikti, 2019). Dengan data-data tersebut diasumsikan perguruan tinggi yang dipilih sudah memiliki kesiapan infrastruktur dan sistem yang mendukung pengembangan pembelajaran daring dan dapat menjadi perwakilan untuk menggambarkan pengembangan pembelajaran daring perguruan tinggi di Indonesia.

\section{HASIL DAN PEMBAHASAN}

LMS merupakan perangkat lunak yang dikembangkan dengan bahasa program tertentu (Java, PHP, Microsoft.NET) dan terintegrasi dengan basis data tertentu (MySQL, Microsoft SQL Server, Oracle). Sebagian besar LMS dikembangkan dengan penyajian berbasis web. LMS merupakan sistem manajemen pembelajaran terintegrasi yang mengelola pengguna, materi ajar, pengaturan peran (pengajar dan siswa), dan pelaporan. LMS juga melakukan penjadwalan, alur pembelajaran, penilaian, forum diskusi, dan persyaratan kelulusan. LMS dikembangkan dengan lisensi komersial dan lisensi open source. Keuntungan sistem aplikasi yang open source memungkinkan setiap pengembang dapat mempelajari, memodifikasi dan mengembangkan perangkat lunak tersebut menjadi sistem yang lebih baik. Beberapa LMS terbaik yang berlisensi open source antara lain Moodle, Chamilo, Open edX, Totara Learn dan Canvas (Pappas, 2019).

LMS yang umumnya digunakan perguruan tinggi di Indonesia adalah aplikasi Moodle. Moodle (Modular Object-Oriented Dynamic Learning Environment) merupakan paket perangkat lunak pembelajaran daring berdasarkan pedagogik konstruktivisme sosial. ITB, ITS, UGM, UI, Tel-U dan SPADA Indonesia menggunakan Moodle dalam mengelola materi kuliah daring (Gambar 1).

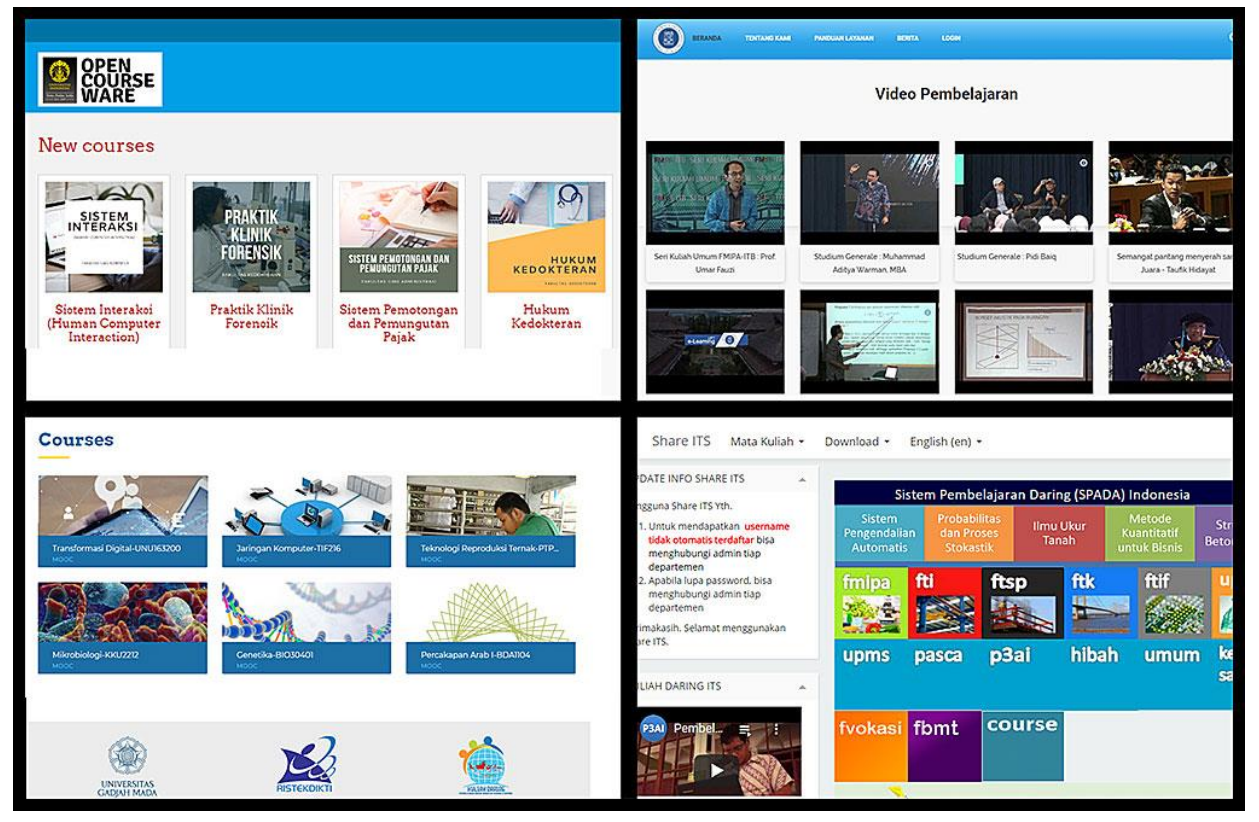

Gambar 1. Sistem pengelolaan pembelajaran daring

[Sumber: diolah dari ocw.ui.ac.id, kuliah.itb.ac.id, , share.its.ac.id, elok.ugm.ac.id] 
Penelitian LMS Moodle di Eastern Mediterranean University menemukan bahwa dosen tidak mengalami kesulitan dengan sistem dan menyarankan untuk menambah opsi pemulihan dan opsi tampilan materi yang fleksibel (Farmanesh \& Samani, 2016). Penelitian LMS Moodle pada universitas di Turki menemukan permasalahan dari sisi mahasiswa. Kurangnya fasilitas umpan balik, kesulitan menemukan obyek, sistem yang membingungkan, tidak memberi petunjuk bagi pengguna awam, terlalu banyak informasi, dan tidak mudah mendapatkan informasi yang dibutuhkan (Erenler, 2018).

Penelitian pada LMS perguruan tinggi di Indonesia dilakukan dengan evaluasi heuristik yang dibagi menjadi 10 variabel penilaian sebagai berikut:

\subsection{Kejelasan Status Sistem}

Sistem yang sulit dipelajari dapat membuat frustasi pengguna dan aktivitas menjadi terhambat. Peserta kuliah daring harus memahami aturan yang terdapat dalam LMS. Bila ada mata kuliah yang tidak dapat diakses berarti mahasiswa tidak diberi hak untuk mengikuti mata kuliah tersebut. Ada mata kuliah yang dapat diikuti oleh mahasiswa, namun harus melakukan prosedur dengan melakukan permintaan password untuk keikutsertaan kuliah (enrollment key) pada dosen pengampu mata kuliah. Terdapat tanda berupa ikon terkait ketersediaan mata kuliah. Pemahaman prosedur ini membutuhkan waktu, sehingga pengguna awam dapat mengalami kebingungan akan proses tersebut (Gambar 2).

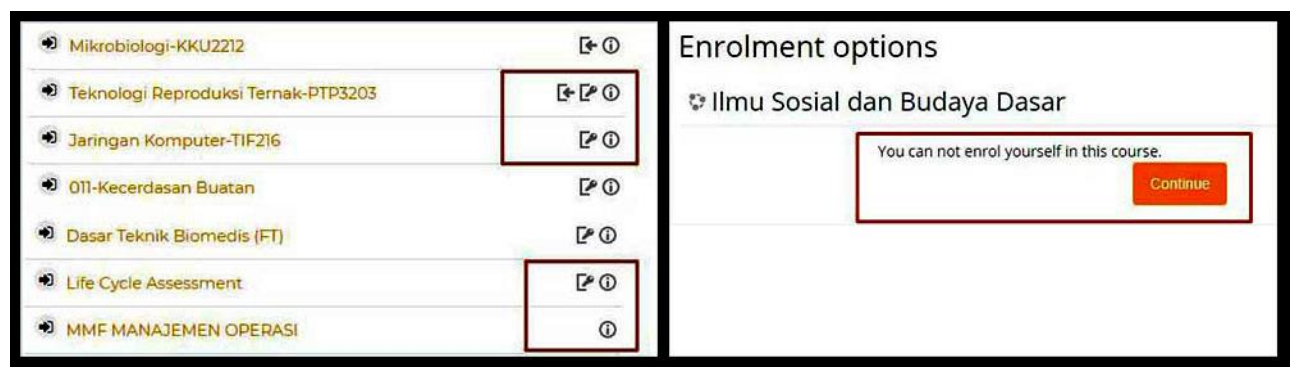

Gambar 2. Opsi pendaftaran (enrolment) mata kuliah daring [Sumber: diolah dari elok.ugm.ac.id dan share.its.ac.id]

\subsection{Perbandingan Antara Sistem dan Dunia Nyata}

Ketika calon siswa akan mengakses materi ajar, dia akan membandingkan dengan konsep perkuliahan konvensional. Yang terdapat di dunia nyata pada setiap mata kuliah adalah terdapat sejumlah pertemuan, masing-masing pertemuan terdapat materi ajar, evaluasi, dan diskusi. Dosen pengampu mata kuliah bertugas mengatur materi dan aktivitas pembelajaran daring dalam LMS. Pengaturan perkuliahan daring yang baik dan informasi yang jelas akan mempermudah peserta perkuliahan untuk memahami materi. Elemen tersebut diatur dengan tampilan visual ikon dan judul dari tiap elemen materi ajar. Masing-masing institusi dapat menggunakan jenis visual yang berbeda untuk tiap elemen yang sama (Gambar 3). 


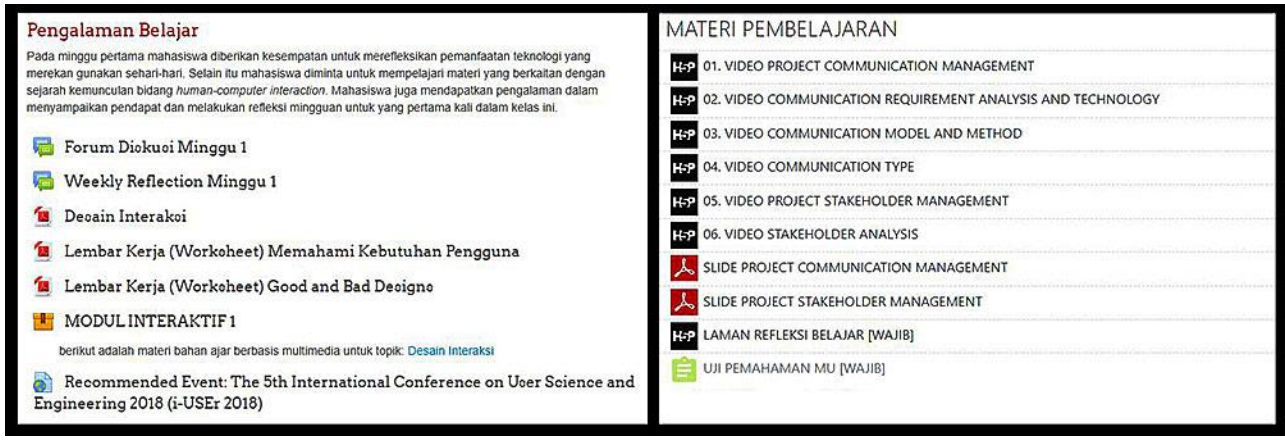

Gambar 3. Konten pengelolaan mata kuliah daring dan aktivitasnya

[Sumber: diolah dari ocw.ui.ac.id dan elearning.telkomuniversity.ac.id]

Untuk penerapan ikon ditemukan beberapa permasalahan. Pada Gambar 4 kolom kiri merupakan tampilan ikon dari pembelajaran daring ITS. Ikon balon tanya jawab yang menjadi perwakilan untuk "Announcements" juga diberikan pada "Questions here". Ikon tersebut merupakan ikon standar untuk forum diskusi, namun penerapannya dapat saja membingungkan pengguna. Hal lain terdapat tiga ikon yang berbeda untuk materi ajar (Introduction to Engineering Statistic, Introductory Statistics dan Basic Statistic). Ketiga ikon itu merepresentasikan gambar dokumen berupa kertas, buku dan file pdf. Siswa sebagai pengguna mungkin akan dibingungkan akan materi ini, apakah ini materi utama atau materi tambahan? Pada materi daring UI (Gambar 4 kolom tengah) terdapat ikon untuk mewakili materi MODUL INTERAKTIF 1 berupa ikon kotak kardus. Hal ini tidak berhubungan dengan dunia nyata pengguna. Pada materi pembelajaran Tel-U (Gambar 4 kolom kanan) terdapat ikon berwarna hitam dengan keterangan teks. Ikon ini sebenarnya simbol untuk video ajar, tapi ikon itu tidak menunjukkan kaitannya.

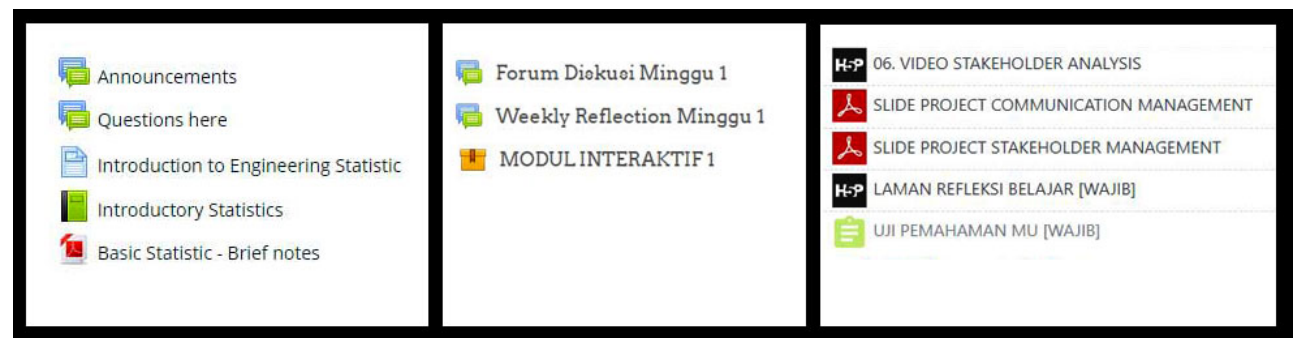

Gambar 4. Penggunaan Ikon materi pembelajaran daring

[Sumber: diolah dari share.its.ac.id, ocw.ui.ac.id dan elearning.telkomuniversity.ac.id]

Prinsip yang mengambil konsep dari dunia nyata disebut sebagai skeuomorphism. Benda-benda yang terkait dunia nyata manusia dicoba untuk diterapkan dalam dunia digital. Ikon metafor lebih baik dalam efisiensi pemberian informasi dibanding ikon nonmetafor (Cho, Kwon, Na, Suk, \& Lee, 2015).

Administrator pengelola LMS institusi dapat mengganti ikon standar yang terdapat pada LMS mereka. Penggunaan ikon dengan abstraksi metafor memudahkan pengguna memberikan korelasi visual mereka dengan dunia nyata. Tingkat realistis ikon sebaiknya pada tingkat ilustratif atau datar (flat) agar tidak membebani ingatan kognitif pengguna. 
Penggunaan ikon bertipe datar juga disarankan oleh penelitian yang terkait dengan permasalahan usability (Spiliotopoulos, Rigou, \& Sirmakessis, 2018).

\subsection{Kontrol Pengguna}

Sistem yang baik dapat memberikan kebebasan pengguna untuk mengendalikan. Kebebasan siswa untuk mengendalikan jalannya materi, termasuk kembali ke materi sebelumnya atau melewatkan materi adalah bagian dari pengendalian ini. Umumnya sistem Moodle sudah memberikan opsi ini. Siswa diberikan kebebasan untuk mengendalikan jalannya materi lewat navigasi atau melalui konten materi (Gambar 5).

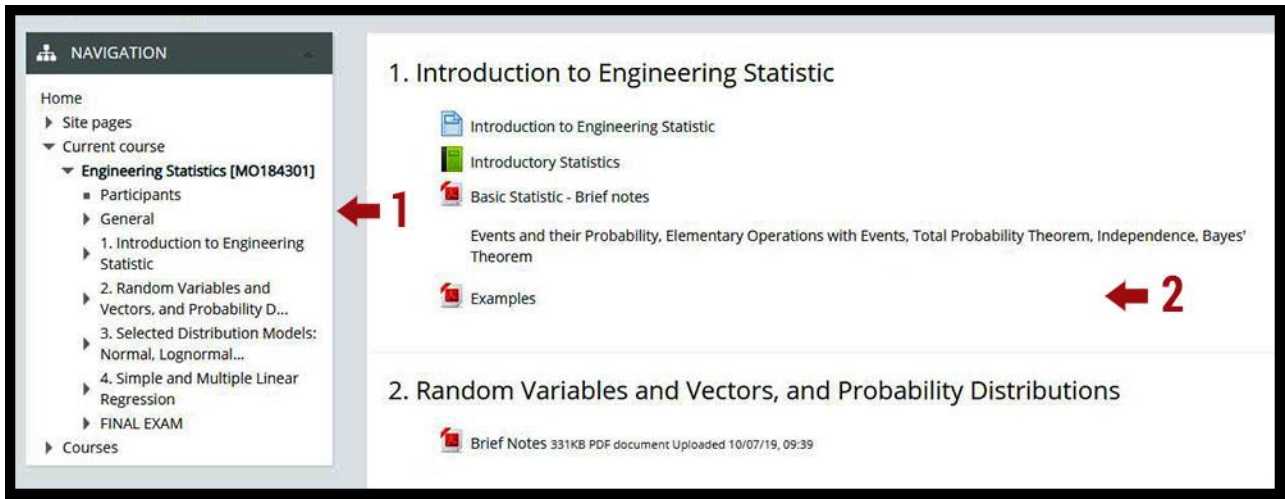

Gambar 5. Kontrol menu navigasi materi ajar (1) dan konten materi ajar (2) [Sumber: diolah dari share.its.ac.id]

Pengamatan pada materi daring UGM ditemukan kekurangan terkait masalah navigasi. Ruangan yang relatif sempit pada bagian navigasi yang terletak di sebelah kanan ini akan menyulitkan pengguna untuk bereksplorasi (Gambar 6). Materi ajar yang mempunyai judul panjang akan membuat padat bagian ini dan akan cenderung menyulitkan pengguna. Penelitian yang terkait dengan persoalan navigasi menunjukkan bahwa navigasi sebelah kiri lebih mudah digunakan pengguna (Thorngate \& Hoden, 2017). Saran untuk permasalahan ini dengan menambah ruang navigasi agar pengguna mudah bereksplorasi dan posisi disarankan untuk diletakkan di bagian kiri.

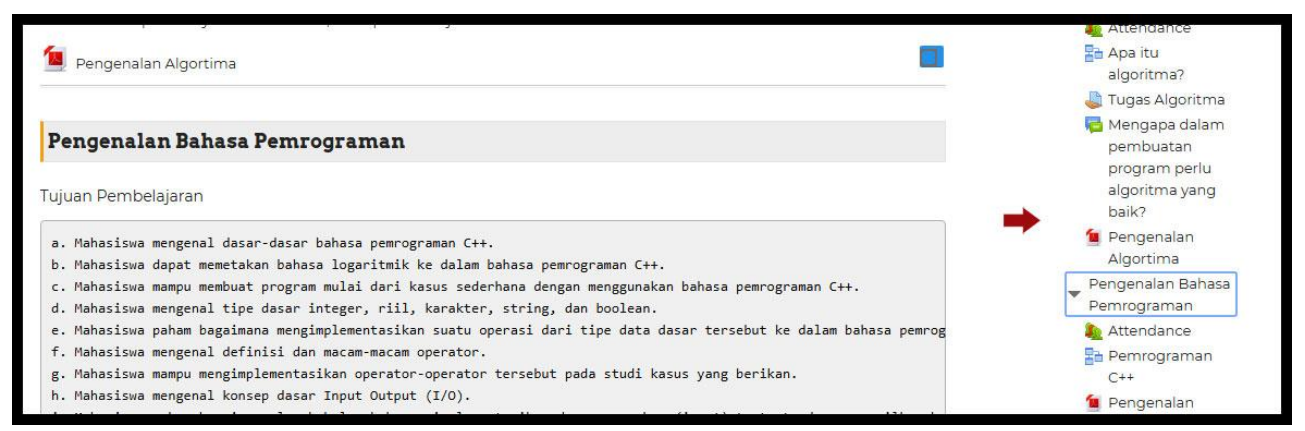

Gambar 6. Kontrol menu navigasi di sebalah kanan yang relatif sempit [Sumber: diolah dari elok.ugm.ac.id] 


\subsection{Konsistensi dan Standar}

LMS perguruan tinggi di Indonesia mendorong peserta kuliah untuk belajar mandiri. Pengaturan konten yang tidak sistematis akan menyulitkan peserta kuliah untuk memahami alur perkuliahan.

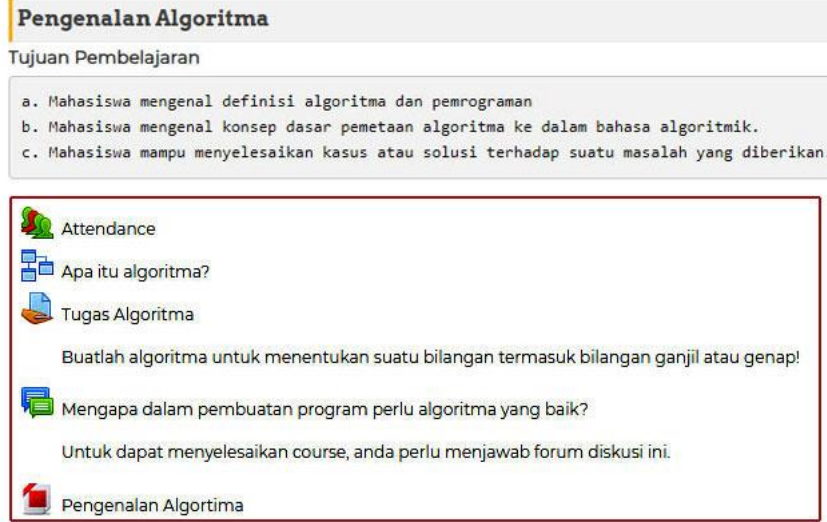

Gambar 7. Elemen materi ajar yang tidak dikategorikan [Sumber: diolah dari elok.ugm.ac.id]

Beberapa mata kuliah tidak diatur dengan baik dalam suatu kategori sehingga peserta kuliah tidak bisa membedakan kategori materi perkuliahan, tautan eksternal, tugas dan bagian evaluasi (Gambar 7). Sarannya dengan penggunaan label yang memberi keterangan elemen materi ajar dan memudahkan dilihat secara sistematis.

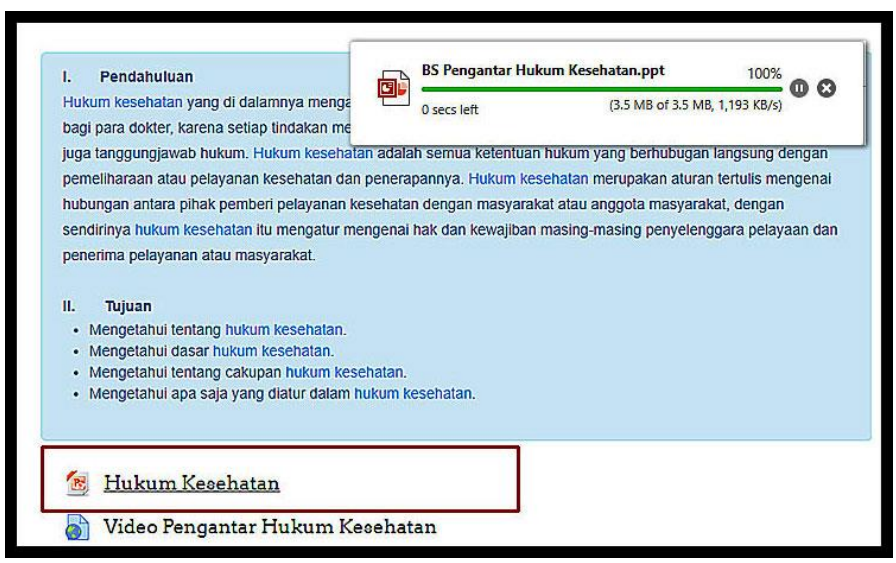

Gambar 8. Materi ajar yang otomatis terunduh [Sumber: diolah dari ocw.ui.ac.id]

Temuan lainnya adalah dokumen materi ajar yang tidak diatur untuk dibuka dalam halaman LMS, melainkan dieksekusi untuk diunduh (Gambar 8). Mahasiswa dapat merasa terpisah dari lingkungan pembelajarannya karena mereka membuka dokumen di tempat yang terpisah. Saran yang dapat dilakukan adalah membuat agar materi ajar tetap berada dalam sistem LMS sesuai dengan prinsip konsistensi dan standar, namun tetap diberi opsi untuk diunduh. 
Pengunduhan dokumen terkait dengan kebebasan mahasiswa untuk mempelajari materi secara luring. Pengintegrasian materi ajar dalam halaman LMS dapat dilakukan dengan dukungan administrator LMS pada institusi masing-masing.

\subsection{Antisipasi Kesalahan}

Dalam proses registrasi perkuliahan umumnya didahului login dengan memasukkan nama pengguna dan kata kunci. Dalam pengamatan ditemukan ketika pengguna memasukkan nama (username) dan kata kunci (password) yang salah, tidak terdapat pemberitahuan bagian mana yang menjadi kesalahan. Fasilitas yang umum diterapkan adalah dengan menampilkan ikon mata yang ada di bagian form password. Hal ini bertujuan apabila pengguna memasukkan password yang salah, ia dapat mengaktifkan ikon mata tersebut untuk memastikan password yang dimasukkannya. Dalam LMS yang diamati, fasilitas ikon mata tidak terdapat dalam bagian login (Gambar 9). Saran untuk masalah ini dengan menambahkan fasilitas tersebut dan pengguna selalu diberitahu apa yang menjadi kesalahannya dalam proses aksi tertentu.

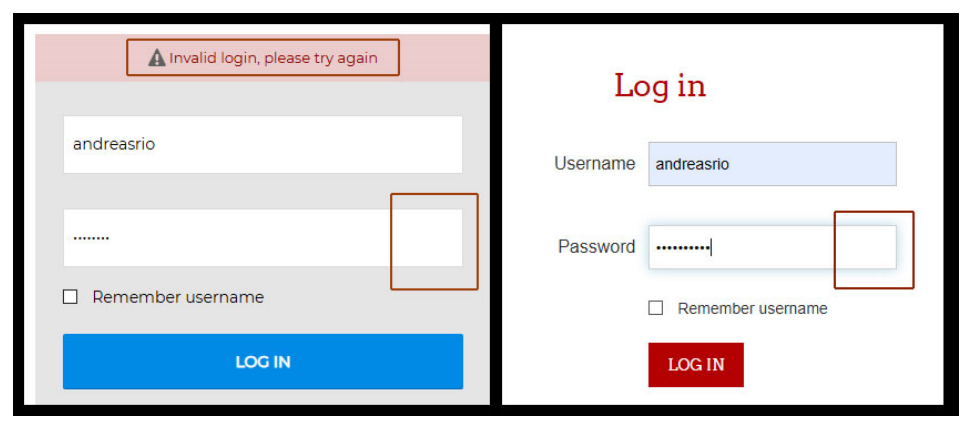

Gambar 9. Tidak ada antisipasi kesalahan pengguna pada area login [Sumber: diolah dari elok.ugm.ac.id dan ocw.ui.ac.id]

\subsection{Mengenali daripada Mengingat}

Konsep ini berhubungan dengan beban ingatan kognitif pengguna. Dengan meminimalkan beban kognitif maka pengguna akan lebih mudah melakukan suatu aksi yang diinginkan. Opsi obyek yang ditampilkan secara visual akan lebih mudah dikenali dibandingkan obyek tulisan yang harus diingat oleh pengguna.

Prinsip ini digunakan untuk menganalisis konten materi pembelajaran daring pada LMS. Materi pembelajaran daring di perguruan tinggi di Indonesia umumnya berfokus pada dosen pengampu mata kuliah. Materi-materi ajar pada pembelajaran daring Indonesia masih memposisikan peserta kuliah daring sebagai penonton dan pembaca materi ajar. Dosen pengampu mata kuliah masih berfungsi sebagai penyedia informasi dan mahasiswa menjadi penerima informasi yang pasif. Materi ajar daring didominasi slide presentasi kuliah di kelas yang diunggah dengan format $p d f$ atau $p p t$. Beberapa materi ajar didominasi slide presentasi dengan tampilan teks yang penuh (Gambar 10). 


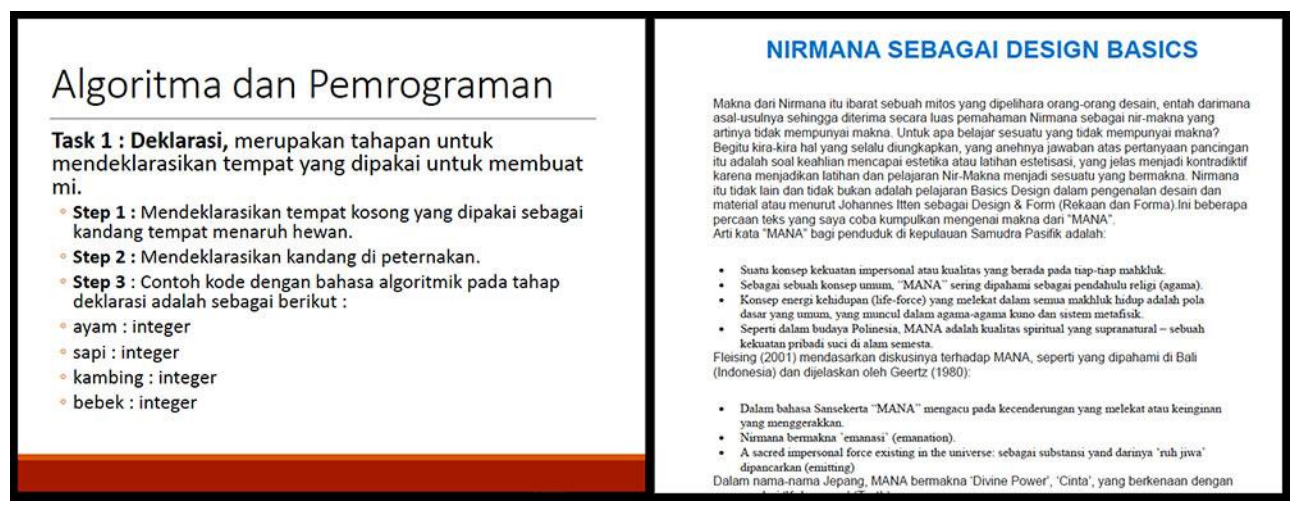

Gambar 10. Materi ajar berupa slide presentasi dengan dominasi teks

[Sumber: diolah dari elok.ugm.ac.id dan ocw.uns.ac.id]

Elemen teks tetap menjadi bagian penting dalam proses pembelajaran. Teks berkoherensi tinggi adalah teks yang dengan kejelasan yang tinggi dan lengkap. Sebuah penelitian membandingkan penggunaan materi teks berkoherensi tinggi dan rendah. Hasilnya, pembaca yang mempunyai berpengetahuan rendah mendapatkan hasil tes yang lebih tinggi dengan menggunakan teks berkoherensi tinggi dibandingkan teks berkoherensi rendah. Sedangkan pembaca berpengetahuan tinggi, membaca teks berkoherensi rendah memberikan hasil yang lebih baik pada tes yang terkait dengan tes pemahaman situasional (McNamara \& Kintsch, 1996). Materi teks komprehensif akan bermanfaat untuk mahasiswa pemula. Materi teks yang lebih ringkas dapat digunakan untuk mahasiswa senior yang pernah mendapatkan pengetahuan terkait. Solusi lain adalah dosen dapat menyediakan dua jenis materi, materi teks komprehensif dan materi teks berupa ringkasan.

Materi ajar bisa berupa gabungan elemen teks dan grafik (Gambar 11). Elemen grafik dalam pembelajaran dapat mempunyai tujuan psikologis (Clark \& Lyons, 2011). Memberikan fungsi perhatian pada elemen yang penting dari materi. Mengaktifkan model mental akan pengetahuan sebelumnya. Meminimalkan beban kognitif dengan penggunaan grafik yang jelas. Membangun model mental dengan melakukan konstruksi pengetahuan baru pada ingatan jangka panjang. Mendukung transfer pembelajaran dengan pemahaman mendalam. Mendukung motivasi dengan penggunaan elemen yang menarik.

Penggunaan elemen grafik juga mempunyai tujuan komunikasi (Clark \& Lyons, 2011). Sebagai elemen dekoratif yang bertujuan menambahkan aspek estetik dan tidak terkait dengan materi. Sebagai elemen representatif yang menampilkan konten materi dalam tampilan yang realistik. Sebagai elemen mnemonik yang berfungsi sebagai alat bantu visual yang dikaitkan dengan fakta atau konsep tertentu. Sebagai elemen organisasional yang menggambarkan hubungan kualitatif dari konten materi. Sebagai elemen relasional yang menggambarkan hubungan kuantitatif antara dua variabel atau lebih. Sebagai elemen transformasional yang mengkomunikasi perubahan yang terjadi dalam suatu periode waktu. Sebagai elemen interpretif yang membantu siswa dengan membangun pemahaman akan proses yang abstrak. 


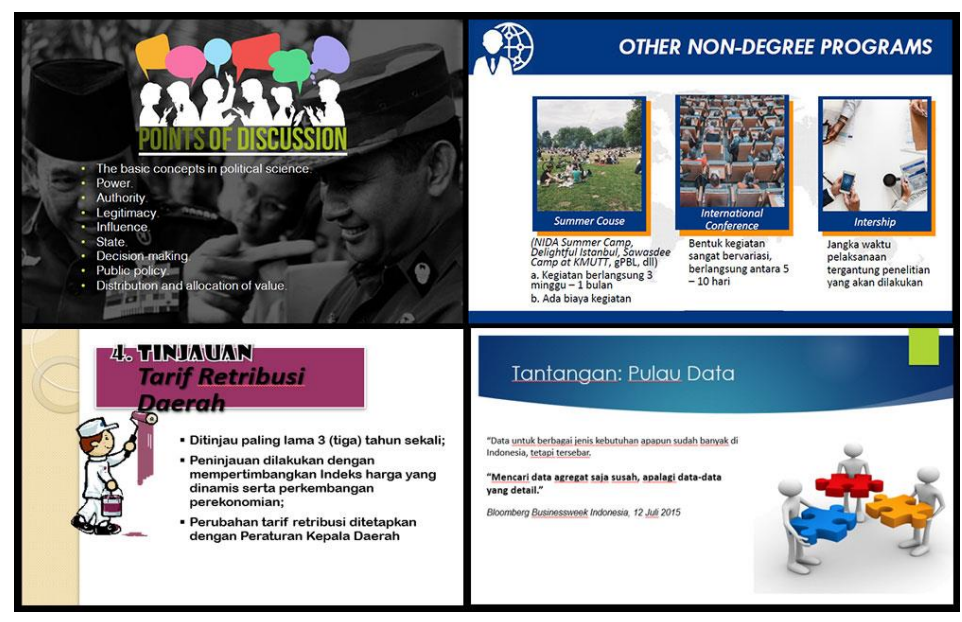

Gambar 11. Materi ajar berupa slide presentasi dengan penerapan elemen gambar yang tidak tepat

[Sumber: diolah dari ocw.ui.ac.id, elok.ugm.ac.id dan share.its.ac.id]

Dengan memperhatikan fungsi psikologis dan komunikasi elemen grafik, dosen dapat menyiapkan elemen grafik dengan memperhatikan fungsinya. Banyak ditemukan penggunaan elemen grafik dengan tujuan dekoratif atau realistik dalam materi ajar dalam LMS (Gambar 11). Fungsi dekoratif tidak membantu siswa mengkonstruksi pengetahuan namun dapat menambah beban kognitif. Sarannya adalah dosen perlu mempertimbangkan elemen gambar yang bersifat organisasional, relasional, transformasional dan interpretif untuk memudahkan siswa dalam mengkonstruksi pengetahuan yang diperoleh.

Materi ajar lainnya adalah video ajar. Video merupakan multimedia yang dapat memberikan informasi lewat dua saluran pengguna, melalui sensor penglihatan dan pendengaran. Beberapa penelitian terkait dengan penggunaan multimedia sebagai media pembelajaran sudah banyak dilakukan. Perancangan pada media pembelajaran berbasis audio visual untuk mata kuliah tipografi dilakukan dengan menerapkan prinsip desain instruksional ADDIE (Sulistiyawati, Prabowo, \& Ulumuddin, 2017). Pengembangan techno virtual berbasis website sebagai media pembelajaran rekayasa visual bagi mahasiswa desain produk (Banindro, 2019). Pengembangan desain informasi dan pembelajaran aksara Jawa melalui media website (Fakhruddin, Sachari, \& Haswanto, 2019). Di sisi lain mahasiswa yang menerima pembelajaran umumnya generasi digital yang terbiasa menggunakan perangkat digital. Hal ini sejalan dengan survei yang menemukan bahwa rata-rata generasi yang lahir setelah tahun 2000 menghabiskan lebih dari lima jam sehari untuk aktivitas secara daring. Namun tingkat literasi aktivitas generasi ini dalam membaca buku masih sangat rendah (Adriyanto, Santosa, \& Syarief, 2019). Melihat kondisi ini, multimedia dapat dijadikan salah satu aspek materi yang memberikan interaktifitas dalam pembelajaran.

Pada video ajar LMS ditemukan video yang merupakan hasil rekaman dalam kelas (Gambar 12). Ada yang melakukan proses perekaman di dalam ruangan dan disisipi materi-materi yang diajarkan. Penggunaan teknik talking-head dengan menampilkan pengajar dalam tampilan bagian kecil dalam video ajar dan materi ajar di bagian 
belakangnya (Gambar 13). Durasi video ajar ini bervariasi mulai dari 10 menit sampai lebih dari satu jam.

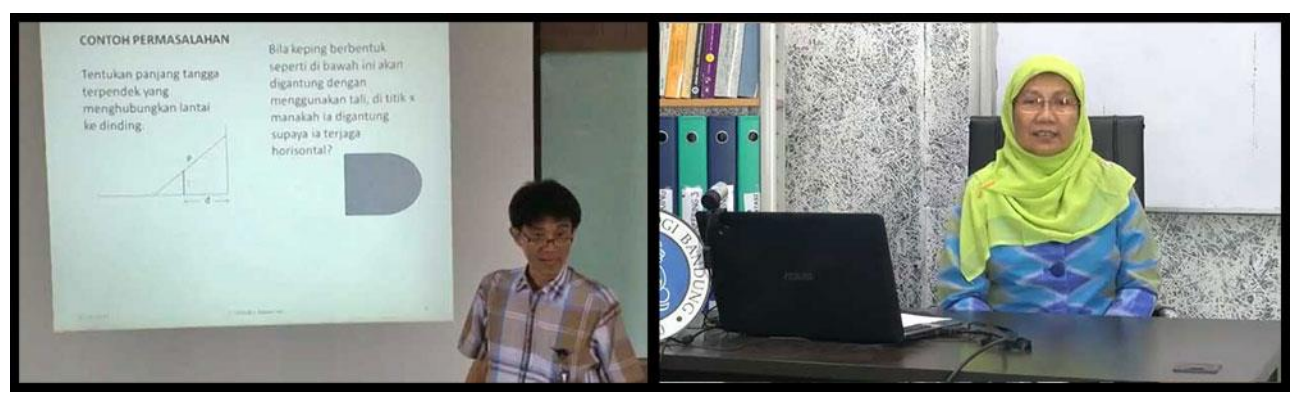

Gambar 12. Video ajar yang direkam langsung di kelas dan di dalam ruangan [Sumber: diolah dari kuliah.itb.ac.id]

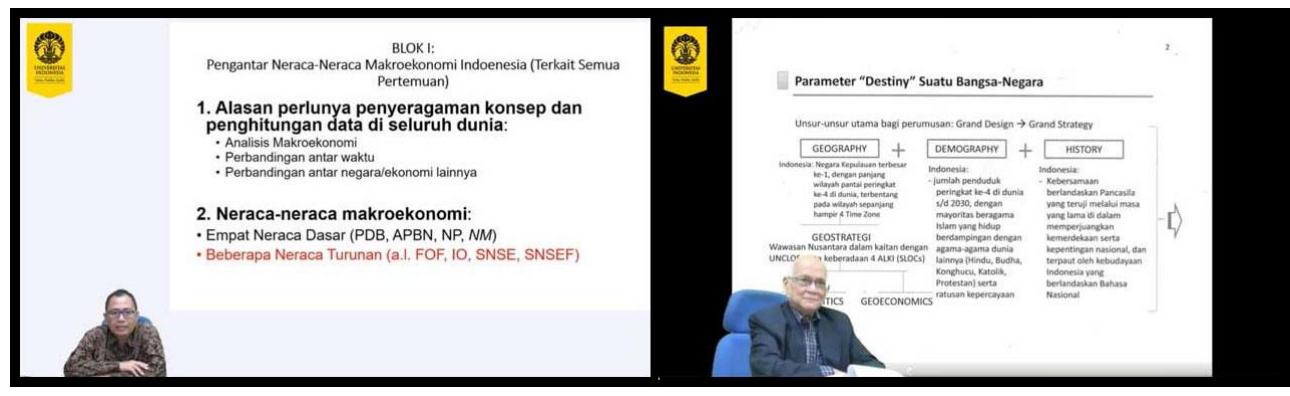

Gambar 13. Video ajar berupa tampilan talking head mini dengan visual materi di belakangnya [Sumber: diolah dari ocw.ui.ac.id]

Sebuah penelitian menjelaskan bahwa video berdurasi pendek lebih meningkatkan keterlibatan siswa dibandingkan berdurasi panjang. Saran penelitian tersebut adalah melakukan segmentasi video dengan durasi kurang dari enam menit (Guo, Kim, \& Rubin, 2014). Beberapa perkuliahan terbuka seperti Coursera menyediakan bagian kuis yang terintegrasi dengan video ajar. Penelitian lain menemukan terdapat tingkat keterikatan pengguna yang tinggi pada video pembelajaran yang terintegrasi kuis. Pengguna mengulang bagian video yang ditonton sebelumnya untuk mendapatkan penjelasan atas pertanyaan dalam kuis (Kovacs, 2016). Dalam proses produksi, dosen dapat membuat rencana dengan membagi pokok bahasan menjadi sub-pokok bahasan yang memuat storyline berdurasi pendek. Elemen interaktifitas dilakukan dengan memasukkan unsur tantangan berupa kuis di bagian-bagian video ajar untuk meningkatkan keterlibatan mahasiswa. Selain mahasiswa dapat mengevaluasi materi yang dilihatnya, mahasiswa juga tidak diperlakukan sebagai penonton.

Prinsip koherensi (Mayer, 2009) menyatakan bahwa materi ekstra yang tidak menjadi bagian utama dalam proses konstruksi pengetahuan sebaiknya dihilangkan. Ini sesuai dengan prinsip beban kognitif ingatan siswa ketika siswa perlu ekstra dalam memproses informasi itu. Siswa yang sedang membaca materi ajar harus juga memproses informasi visual tampilan talking-head dosen yang berbicara di sudut kiri bawah (Gambar 13). Gambar 14 kolom kiri terdapat video ajar yang tampilan latar, materi ajar teks yang terdapat grafik dekoratif dan dosen yang berbicara di depan mereka. Proses ini dapat 
menambah beban kognitif mahasiswa. Motion graphic yang menampilkan elemen grafik yang tidak memudahkan mahasiswa dalam mengkonstruksi pengetahuan sebaiknya dihindari (Gambar 14, kolom kanan).

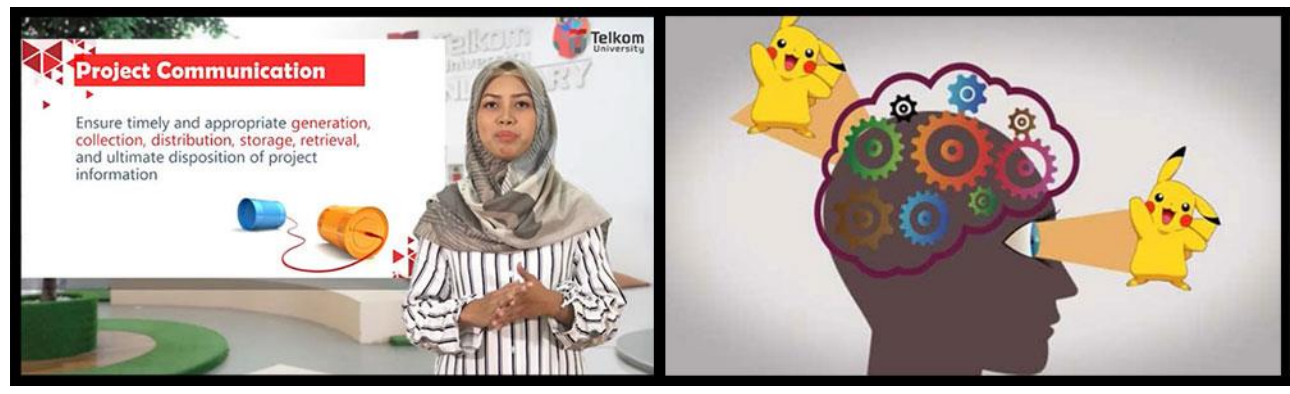

Gambar 14. Video ajar dengan elemen grafis yang menambah beban kognitif [Sumber: diolah dari elearning.telkomuniversity.ac.id dan kuliah.itb.ac.id]

\subsection{Fleksibilitas dan Efisiensi Penggunaan}

Langkah yang banyak dan bertahap dalam menyelesaikan suatu aksi akan lebih menyulitkan dibandingkan sebuah langkah yang efisien. Dalam LMS ditemukan kondisi ketika mahasiswa ingin mencari mata kuliah, ia harus mencari tiap halaman dan memperhatikan nama setiap kuliah yang ditemui. Penggunaan penomoran halaman akan semakin menyulitkan pengguna ketika konten bertambah banyak (Gambar 15).

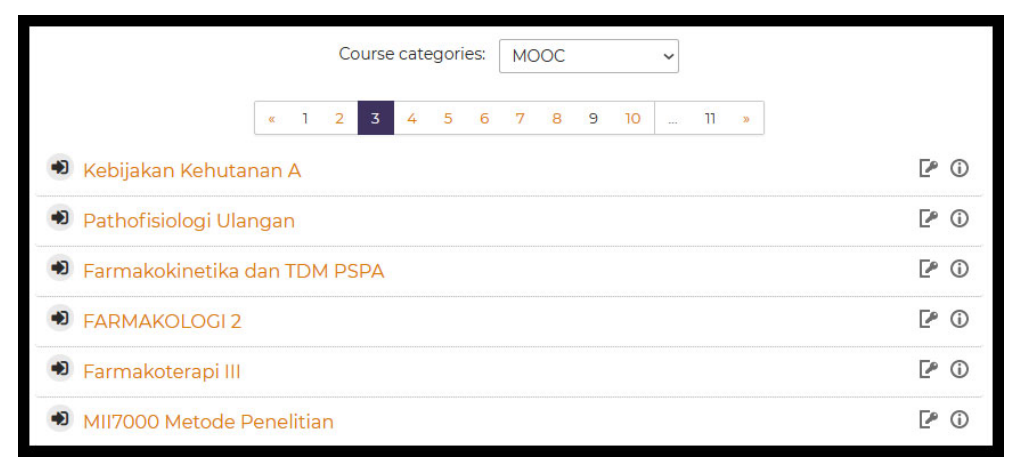

Gambar 15. Navigasi materi ajar tanpa opsi pencarian

[Sumber: diolah dari elok.ugm.ac.id]

Tampilan menggunakan menu drop-down (Gambar 16) membuat pengguna dapat melihat secara sistematis dan struktur dari konten materi. Namun dengan bertambahnya konten, navigasi ini akan menyulitkan pengguna. Saran untuk permasalahan ini adalah pengguna diberikan kesempatan untuk melakukan pencarian secara fleksibel. Penggunaan form pencarian dapat menjadi solusi. 


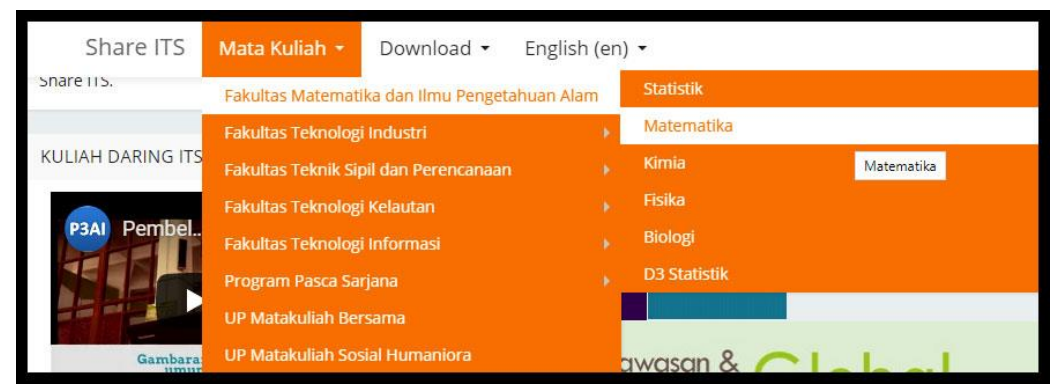

Gambar 16. Navigasi menu drop-down materi ajar tanpa opsi pencarian

[Sumber: diolah dari share.its.ac.id]

\subsection{Estetika dan Desain Minimalis}

Elemen-elemen informasi diproses untuk meningkatkan efisiensi komunikasi kepada pengguna dalam menyelesaikan tugasnya. Bila ada elemen yang tidak mendukung tujuan informasi maka akan menyulitkan pengguna. Dalam LMS ditemukan bahwa tiap materi perkuliahan ditampilkan secara keseluruhan. Bila ada 14 kali pertemuan, maka 14 pertemuan tersebut ditampilkan dalam satu halaman (Gambar 17). Hal ini dapat menyebabkan mahasiswa sulit mengontrol materi terutama jika mereka harus mencari materi mana yang terakhir dipelajari. Saran untuk permasalahan ini adalah menampilkan opsi tampilan halaman tiap satu pertemuan atau satu sub-pokok bahasan. Kemungkinan lain adalah bila ingin menampilkan seluruh pertemuan dapat dilakukan dengan memberikan opsi accordion menu pada tiap pertemuan sehingga dapat dibuka dan ditutup sementara waktu.

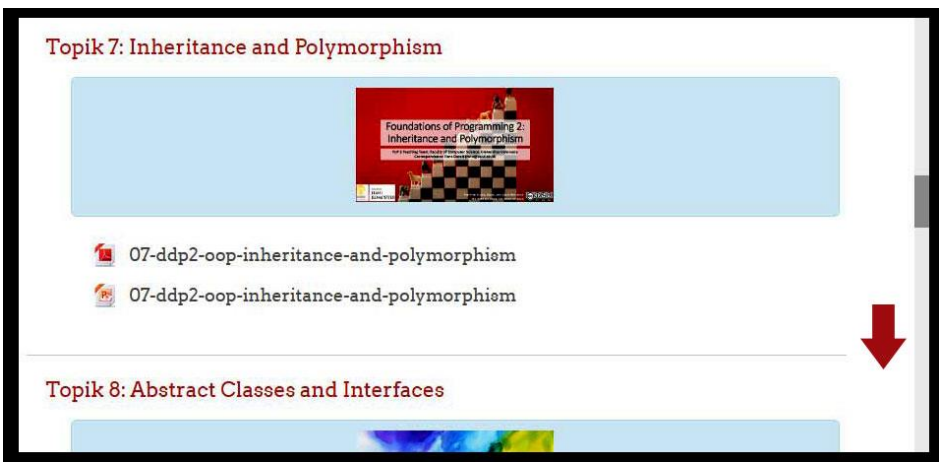

Gambar 17. Seluruh topik materi ditampilkan dalam satu layar [Sumber: diolah dari ocw.ui.ac.id]

\subsection{Membantu Pengguna Mendeteksi, Mendiagnosis dan Menyelesaikan Kesalahan}

Pengamatan pada LMS ditemukan masalah dalam proses log in. Mahasiswa diminta memasukkan username dan password. Bila terjadi kesalahan input seharusnya sistem dapat memberitahukan kesalahan yang sedang terjadi, memberitahu kepada pengguna apa yang menjadi kesalahan dan memberikan solusi atas aksi yang salah tersebut. Pada Gambar 18 adalah tampilan ketika pengguna salah memasukkan password, namun tidak dijelaskan apakah pengguna salah memasukkan username atau password. Kemudian ada tampilan untuk log in sebagai tamu (Log in as a guest). Bila pengguna tidak paham sistem pada LMS tersebut dapat menyebabkan frustasi dalam mengaksesnya. 


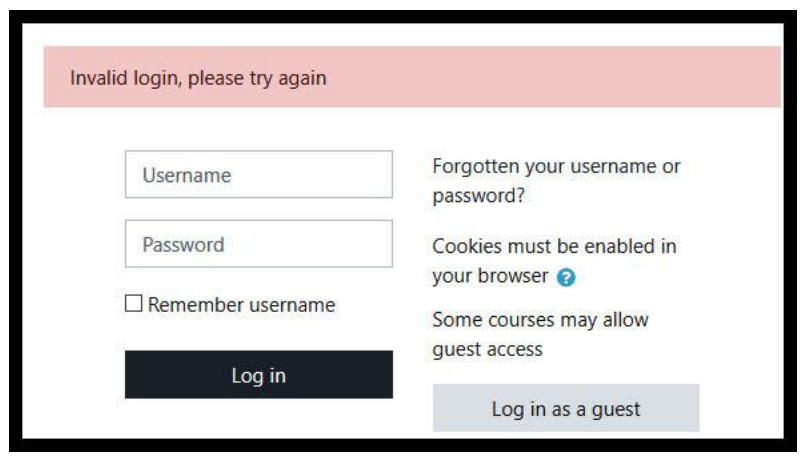

Gambar 18. Contoh informasi pada halaman login yang tidak ada informasi lebih lanjut

[Sumber: diolah dari elearning.telkomuniversity.ac.id]

Pada LMS yang lain ditemukan ketika pengguna salah memasukkan informasi di bagian log in kemudian dipindahkan ke halaman yang terlihat pada Gambar 19. Keterangan ditampilkan dengan bahasa teknis yang berisi informasi infrastruktur dan sistem. Saran untuk permasalahan ini, pihak administrator LMS dapat membenahi sistem dengan mempermudah pengguna mengetahui kesalahan yang sedang terjadi. Penggunaan bahasa Indonesia dapat menjadi pertimbangan dalam menyampaikan dialog kepada calon pengguna, terutama untuk mata kuliah terbuka yang para penggunanya belum terbiasa dengan LMS yang ada.

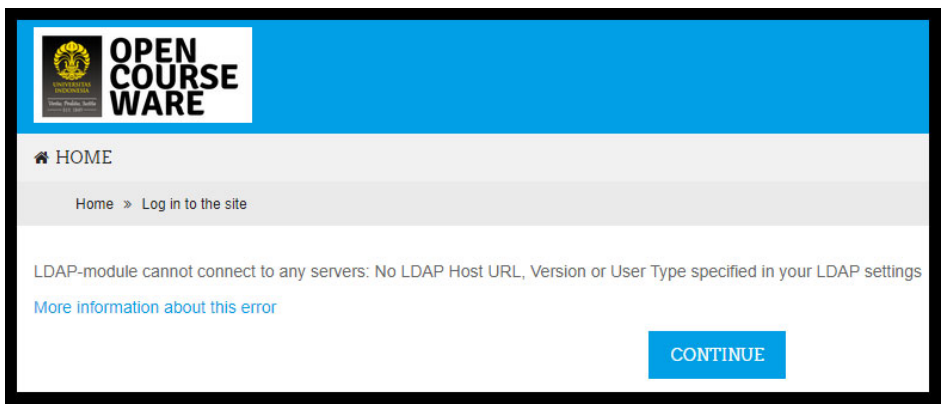

Gambar 19. Contoh tanggapan kesalahan dari halaman login yang bersifat teknis [Sumber: diolah dari ocw.ui.ac.id]

\subsection{Dokumentasi dan Bantuan}

Pada LMS ditemukan institusi yang sudah menerapkan panduan bagi pengguna. Formatnya berupa dokumen $p d f$ atau video tutorial. Namun ditemukan juga LMS yang belum dilengkapi dengan dokumen bantuan, tautan yang tidak berisi informasi yang terkait dengan bantuan pengguna bagi pemahaman sistem yang ada (Gambar 20). 


\section{OPEN} CORS

Materi kuliah dari berbagai pakar di Universitas Indonesia untuk pembelajar yang dapat diakses secara gratis tanpa terbatas ruang dan waktu. Materi kuliah tersedia secara daring dan dapat diakses/diunduh kapan saja dan dan mana saja.
INFO

Kuliah daring

Kuliah terbuka

Materi terbuka

Makara internet TV UI

\section{Gambar 20. Contoh informasi bantuan yang tidak berisi konten bantuan yang dibutuhkan pengguna \\ [Sumber: diolah dari ocw.ui.ac.id]}

Ada juga yang tidak berisi informasi apapun dalam bagian tersebut (Gambar 21). Hal ini perlu diperhatikan mengingat pembelajaran daring yang ditawarkan merupakan kuliah terbuka dengan peserta dari luar institusi. Saran untuk permasalahan ini adalah pihak pengelola layanan dapat melengkapi dengan opsi bantuan mengingat pembelajaran daring membutuhkan kemandirian siswa sehingga informasi yang lengkap dan menyeluruh dapat mengantisipasi kesalahan yang diakibatkan oleh pengguna.

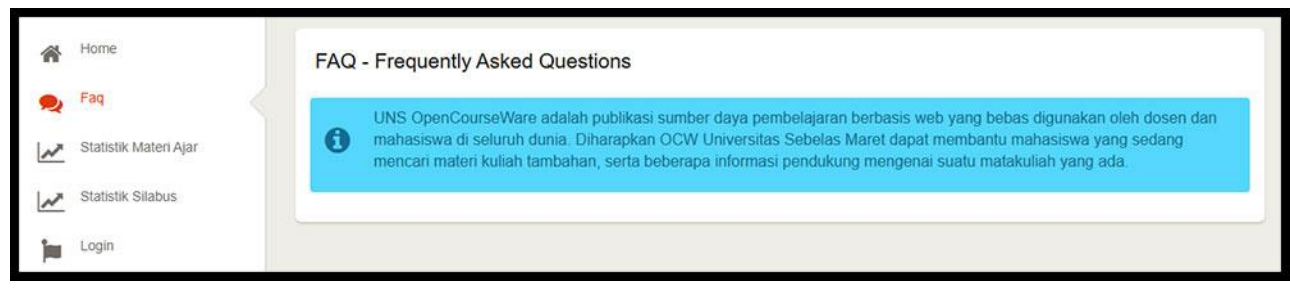

Gambar 21. Contoh informasi bantuan yang belum lengkap [Sumber: diolah dari ocw.uns.ac.id]

Hasil keseluruhan evaluasi heuristik pada LMS perguruan tinggi di Indonesia dijelaskan dalam Tabel 1 yang terdiri dari variabel yang diukur, temuan, tingkat keparahan atau Severity Rating (SR) dan rekomendasi atas permasalahan itu. Severity Rating merupakan tingkat keparahan dari sistem yang diamati. Skala yang digunakan dari 0 sampai 4 (Nielsen, 1994). Nilai 0 menunjukkan tidak ada permasalahan. Nilai 1 terdapat permasalahan kosmetik, nilai 2 terdapat permasalahan minor, nilai 3 terdapat permasalahan mayor dan nilai 4 terdapat permasalahan utama.

Tabel 1. Evaluasi heuristik sistem pengelolaan pembelajaran daring perguruan tinggi di Indonesia

[Sumber: Dokumentasi penulis, 2020]

\begin{tabular}{|c|c|c|c|}
\hline $\begin{array}{l}\text { Variabel } \\
\text { Penilaian }\end{array}$ & Temuan & SR & Rekomendasi \\
\hline $\begin{array}{l}\text { Kejelasan } \\
\text { status sistem }\end{array}$ & $\begin{array}{l}\text { 1) Prosedur mengikuti mata } \\
\text { kuliah yang tidak jelas } \\
\text { 2) Penggunaan ikon yang tidak } \\
\text { jelas dalam keterangan } \\
\text { keikutsertaan }\end{array}$ & 2 & $\begin{array}{l}\text { 1) Pengelola LMS perlu } \\
\text { memberitahukan prosedur } \\
\text { perkuliahan daring dengan } \\
\text { dokumen panduan atau } \\
\text { halaman khusus }\end{array}$ \\
\hline
\end{tabular}




\begin{tabular}{|c|c|c|c|c|}
\hline $\begin{array}{l}\text { Variabel } \\
\text { Penilaian }\end{array}$ & & Temuan & SR & Rekomendasi \\
\hline $\begin{array}{l}\text { Perbandingan } \\
\text { antara sistem } \\
\text { dan dunia } \\
\text { nyata }\end{array}$ & & $\begin{array}{l}\text { Pengaturan materi-materi ajar } \\
\text { dan ikon dapat disalahartikan } \\
\text { oleh mahasiswa }\end{array}$ & 1 & $\begin{array}{l}\text { 1) Mengganti ikon standar } \\
\text { pada LMS dengan ikon yang } \\
\text { memberikan korelasi visual }\end{array}$ \\
\hline $\begin{array}{l}\text { Kontrol } \\
\text { pengguna }\end{array}$ & & $\begin{array}{l}\text { Penggunaan navigasi dalam } \\
\text { ruang yang relatif sempit } \\
\text { sehingga menyulitkan } \\
\text { mahasiswa }\end{array}$ & 1 & $\begin{array}{l}\text { 1) Mengatur lagi sistem } \\
\text { navigasi yang } \\
\text { mempermudah mahasiswa } \\
\text { bereksplorasi }\end{array}$ \\
\hline $\begin{array}{l}\text { Konsistensi } \\
\text { dan standar }\end{array}$ & $\begin{array}{l}\text { 1) } \\
\text { 2) }\end{array}$ & $\begin{array}{l}\text { Terdapat ketidakjelasan } \\
\text { dalam pengaturan materi- } \\
\text { materi ajar } \\
\text { Terdapat dokumen materi } \\
\text { ajar yang diberi pilihan hanya } \\
\text { diunduh }\end{array}$ & 2 & $\begin{array}{l}\text { 1) Pengaturan materi ajar } \\
\text { dengan label. } \\
\text { 2) Akses materi ajar } \\
\text { diintegrasikan ke dalam } \\
\text { halaman LMS dengan opsi } \\
\text { untuk diunduh }\end{array}$ \\
\hline $\begin{array}{l}\text { Antisipasi } \\
\text { kesalahan }\end{array}$ & 1) & $\begin{array}{l}\text { Tidak ada fasilitas ikon mata } \\
\text { untuk melihat password } \\
\text { sehingga pengguna tidak } \\
\text { dapat memastikan password }\end{array}$ & 2 & $\begin{array}{l}\text { 1) Menambahkan fasilitas } \\
\text { tersebut dan pengguna } \\
\text { selalu diberitahu apa yang } \\
\text { menjadi kesalahannya dalam } \\
\text { proses aksi tertentu }\end{array}$ \\
\hline $\begin{array}{l}\text { Mengenali } \\
\text { daripada } \\
\text { mengingat }\end{array}$ & $\begin{array}{l}\text { 1) } \\
\text { 2) } \\
\text { 3) } \\
\text { 4) } \\
\text { 5) }\end{array}$ & $\begin{array}{l}\text { Terdapat materi ajar yang } \\
\text { berisi poin-poin utama saja } \\
\text { tanpa penjelasan lebih lanjut } \\
\text { Terdapat materi ajar yang } \\
\text { berisi keterangan penjelasan } \\
\text { yang panjang } \\
\text { Terdapat materi ajar dengan } \\
\text { elemen grafik yang tidak tepat } \\
\text { Terdapat video ajar yang } \\
\text { melakukan proses perekaman } \\
\text { di kelas dengan durasi yang } \\
\text { panjang } \\
\text { Terdapat video ajar yang } \\
\text { menggunakan elemen ekstra } \\
\text { yang tidak terkait dengan } \\
\text { bahan ajar }\end{array}$ & 3 & $\begin{array}{l}\text { 1) Penggunaan materi teks } \\
\text { yang komprehensif untuk } \\
\text { mahasiswa pemula } \\
\text { 2) Penggunaan materi teks } \\
\text { yang lebih ringkas dan hal- } \\
\text { hal yang penting untuk } \\
\text { mahasiswa yang senior } \\
\text { 3) Dosen dapat menyediakan } \\
\text { materi teks komprehensif } \\
\text { dan materi teks ringkasan } \\
\text { 4) Mempertimbangkan elemen } \\
\text { grafik sesuai fungsinya } \\
\text { 5) Membagi video ajar dalam } \\
\text { segmentasi durasi yang lebih } \\
\text { pendek dan memasukkan } \\
\text { unsur tantangan dalam } \\
\text { bagian video } \\
\text { 6) Menampilkan elemen- } \\
\text { elemen grafik dalam video } \\
\text { ajar yang relevan dengan } \\
\text { proses konstruksi } \\
\text { pengetahuan mahasiswa. }\end{array}$ \\
\hline $\begin{array}{l}\text { Fleksibilitas } \\
\text { dan efisiensi } \\
\text { penggunaan }\end{array}$ & $\begin{array}{l}\text { 1) } \\
\text { 2) }\end{array}$ & $\begin{array}{l}\text { Terdapat navigasi materi ajar } \\
\text { tanpa opsi pencarian } \\
\text { Terdapat penggunaan menu } \\
\text { drop-down yang berpotensi } \\
\text { menimbulkan masalah ketika } \\
\text { materi bertambah banyak }\end{array}$ & 2 & $\begin{array}{l}\text { 1) Memberikan alternatif } \\
\text { navigasi sehingga dapat } \\
\text { melakukan pencarian secara } \\
\text { fleksibel }\end{array}$ \\
\hline
\end{tabular}




\begin{tabular}{|c|c|c|c|}
\hline $\begin{array}{l}\text { Variabel } \\
\text { Penilaian }\end{array}$ & Temuan & SR & Rekomendasi \\
\hline & & & $\begin{array}{l}\text { 2) Memasukkan form } \\
\text { pencarian sebagai salah satu } \\
\text { alternatif }\end{array}$ \\
\hline $\begin{array}{l}\text { Estetika dan } \\
\text { desain } \\
\text { minimalis }\end{array}$ & $\begin{array}{l}\text { 1) Terdapat pertemuan dalam } \\
\text { satu mata kuliah yang } \\
\text { ditampilkan secara langsung } \\
\text { dalam satu halaman }\end{array}$ & 2 & $\begin{array}{l}\text { 1) Menampilkan tampilan tiap } \\
\text { satu pertemuan atau satu } \\
\text { sub-pokok bahasan } \\
\text { 2) Penggunaan menu accordion } \\
\text { yang dapat dibuka tutup }\end{array}$ \\
\hline $\begin{array}{l}\text { Membantu } \\
\text { pengguna } \\
\text { mendeteksi, } \\
\text { mendiagnosis } \\
\text { dan } \\
\text { menyelesaikan } \\
\text { kesalahan }\end{array}$ & $\begin{array}{l}\text { 1) Tidak ada informasi ketika } \\
\text { masalah terjadi dalam proses } \\
\text { log in } \\
\text { 2) Terdapat bagian halaman } \\
\text { yang tidak berisi informasi } \\
\text { apapun ketika pengguna salah } \\
\text { melakukan suatu aksi }\end{array}$ & 2 & $\begin{array}{l}\text { 1) Perlu ditambahkan suatu } \\
\text { informasi yang } \\
\text { memberitahukan ketika } \\
\text { pengguna melakukan } \\
\text { kesalahan aksi } \\
\text { 2) Halaman yang terkait sistem } \\
\text { perlu dicek ulang untuk } \\
\text { antisipasi kesalahan }\end{array}$ \\
\hline $\begin{array}{l}\text { Dokumentasi } \\
\text { dan bantuan }\end{array}$ & $\begin{array}{l}\text { 1) Tidak ditemukan bagian yang } \\
\text { membantu pengguna untuk } \\
\text { memahami sistem } \\
\text { 2) Terdapat halaman informasi } \\
\text { panduan yang belum lengkap } \\
\text { terisi }\end{array}$ & 2 & $\begin{array}{l}\text { 1) Administrator sistem LMS } \\
\text { perlu melengkapi bagian- } \\
\text { bagian yang masih kurang } \\
\text { dan melengkapi panduan } \\
\text { bagi pengguna }\end{array}$ \\
\hline \multicolumn{2}{|c|}{ Total tingkat keparahan } & 1,9 & \\
\hline
\end{tabular}

Keterangan SR: 0: tidak ada permasalahan sama sekali 1: permasalahan kosmetik 2: permasalahan minor 3: permasalahan mayor 4: permasalahan utama

Dari hasil penilaian tingkat keparahan (SR) LMS yang diamati secara keseluruhan didapatkan nilai rata-rata dengan skor 1,9. Hal ini menunjukkan secara keseluruhan permasalahan masih tergolong permasalahan minor.

\section{KESIMPULAN}

Walaupun permasalahan yang terdapat dalam LMS masih tergolong minor namun untuk variabel yang terkait materi ajar didapatkan nilai 3 yang menjadikan materi ajar ini mempunyai permasalahan yang harus dibenahi. Kemandirian mahasiswa dalam mengikuti perkuliahan daring menjadi pertimbangan utama. Karena kemandirian itu, kejelasan materi ajar dan kemudahan dalam aktivitas pembelajaran menjadi krusial untuk diterapkan. Pemahaman penggunaan elemen teks dan grafik serta fungsifungsinya dalam materi ajar perlu dijelaskan secara mendalam pada dosen pengampu. Penggunaan video ajar perlu mempertimbangkan aspek kognitif dan preferensi siswa. Rekomendasi penelitian ini dapat ditindaklanjuti oleh administrator LMS institusi dan dosen pengampu mata kuliah.

Kekurangan dalam penelitian ini adalah masih melihat secara global untuk keseluruhan sistem LMS dan materi ajar yang ada di institusi pendidikan tinggi. Penelitian lebih lanjut dan detil dapat difokuskan kepada salah satu jenis LMS seperti institusi di luar pendidikan tinggi dengan aplikasi di luar Moodle dan penggunaan platform yang 
berbeda seperti pada perangkat mobile. Dengan memperbanyak kasus dalam berbagai pembelajaran daring dapat memperkaya dan melengkapi penelitian-penelitian sejenis. Penelitian yang mendalam perlu dilakukan dengan fokus pada materi ajar, posisi keilmuan desain komunikasi visual dapat memberikan kontribusi terkait permasalahan visual materi ajar. Namun dengan kajian global ini, saran dan rekomendasi yang telah diajukan diharapkan dapat mengurangi kekurangan-kekurangan yang ada secara umum dalam LMS masing-masing institusi. Perbaikan dan pengembangan lebih lanjut diharapkan dapat meningkatkan kualitas pembelajaran daring di institusi perguruan tinggi Indonesia.

\section{DAFTAR PUSTAKA}

Adriyanto, A. R., Santosa, I., \& Syarief, A. (2019). Memahami Perilaku Generasi Z Sebagai Dasar Pengembangan Materi Pembelajaran Daring. Prosiding Seni, Teknologi Dan Masyarakat \#4, 2, 165-173.

Banindro, B. S. (2019). Pengembangan Techno Virtual Berbasis Website sebagai Media Pembelajaran Rekayasa Visual Blender 3D bagi Mahasiswa Desain Produk. ANDHARUPA: Jurnal Desain Komunikasi Visual \& Multimedia, 5(01), 102-114.

Bhuasiri, W., Xaymoungkhoun, O., Zo, H., Rho, J. J., \& Ciganek, A. P. (2012). Critical success factors for e-learning in developing countries: A comparative analysis between ICT experts and faculty. Computers \& Education, 58(2), 843-855.

Cho, M., Kwon, S., Na, N., Suk, H.-J., \& Lee, K. (2015). The Elders Preference for Skeuomorphism as App Icon Style. Proceedings of the 33rd Annual ACM Conference Extended Abstracts on Human Factors in Computing Systems - CHI EA'15, 899-904.

Clark, R. C., \& Lyons, C. (2011). Graphics for Learning: Proven Guidelines for Planning, Designing, and Evaluating Visuals in Training Materials (Second). San Francisco: Pfeiffer.

Erenler, H. H. T. (2018). Heuristic Evaluation of E-Learning. International Journal of Organizational Leadership , 7, 195-210.

Fakhruddin, D., Sachari, A., \& Haswanto, N. (2019). Pengembangan Desain Informasi dan Pembelajaran Aksara Jawa melalui Media Website. ANDHARUPA: Jurnal Desain Komunikasi Visual \& Multimedia, 5(01), 1-23.

Farmanesh, P., \& Samani, A. A. (2016). Heuristic Evaluation of the Usability of Learning Management System (Moodle) at Eastern Mediterranean University. International Journal of Scientific Research in Information Systems and Engineering (IJSRISE), 2(1), 22-36.

Guo, P. J., Kim, J., \& Rubin, R. (2014). How video production affects student engagement. Proceedings of the First ACM Conference on Learning@ Scale Conference - L@S '14, 41-50.

Kemenristekdikti. (2018). Panduan Hibah Penyelenggaraan Sistem Pembelajaran Daring (SPADA) Indonesia Tahun 2018. Direktorat Pembelajaran, Direktorat Jenderal Pembelajaran dan Kemahasiswaan, Kementerian Riset Teknologi dan Pendidikan Tinggi Republik Indonesia. 
Kemenristekdikti. (2019). Menristekdikti Umumkan Klasterisasi Perguruan Tinggi Indonesia 2019, Fokuskan Hasil dari Perguruan Tinggi. Retrieved July 12, 2020, from https://www.ristekbrin.go.id/kabar/menristekdikti-umumkanklasterisasi-perguruan-tinggi-indonesia-2019-fokuskan-hasil-dari-perguruantinggi/

Kompas. (2020). Gotong Royong Studi Daring. pp. 9-9.

Kovacs, G. (2016). Effects of In-Video Quizzes on MOOC Lecture Viewing. Proceedings of the Third (2016) ACM Conference on Learning @ Scale - L@S '16, 31-40.

Mayer, R. E. (2009). Multimedia Learning (Second). Cambridge: Cambridge University Press.

McNamara, D. S., \& Kintsch, W. (1996). Learning from texts: Effects of prior knowledge and text coherence. Discourse Processes, 22(3), 247-288.

Nielsen, J. (1994). Usability inspection methods. New York: John Wiley \& Sons.

Pappas, C. (2019). The 20 Best Learning Management Systems (2019 Update). Retrieved July 12, 2020, from https://elearningindustry.com/the-20-best-learningmanagement-systems

Spiliotopoulos, K., Rigou, M., \& Sirmakessis, S. (2018). A Comparative Study of Skeuomorphic and Flat Design from a UX Perspective. Multimodal Technologies and Interaction, 2(2), 31.

Sulistiyawati, P., Prabowo, D. P., \& Ulumuddin, D. I. I. (2017). Perancangan Media Pembelajaran Berbasis Audio Visual untuk Mata Kuliah Tipografi pada Program Studi Desain Komunikasi Visual Universitas Dian Nuswantoro. ANDHARUPA: Jurnal Desain Komunikasi Visual \& Multimedia, 3(01), 69-80.

Thorngate, S., \& Hoden, A. (2017). Exploratory Usability Testing of User Interface Options in LibGuides 2. College \& Research Libraries, 78(6).

Zhang, D., Zhao, J. L., Zhou, L., \& Nunamaker, J. F. (2004). Can e-learning replace classroom learning? Communications of the ACM, 47(5), 75-79. 